\title{
Cardiac Nerve Plexus
}

National Cancer Institute

\section{Source}

National Cancer Institute. Cardiac Nerve Plexus. NCI Thesaurus. Code C52833.

A network of nerves that arises from the superior cardiac branch of the sympathetic trunk and lower superior cervical branch of the vagus which innervates the aortic arch, coronary vessels, pulmonary artery, and the heart. 